\title{
ВЛИЯНИЕ ГЕОЛОГИЧЕСКИХ РАБОТ НА ПОВЕРХНОСТНЫЕ ВОДЫ И ДОННЫЕ ОТЛОЖЕНИЯ АЙХАЛЬСКОГО ГОРНОПРОМЫШЛЕННОГО КОМПЛЕКСА (ЯКУТИЯ)
}

\author{
М. А. Хованская, М. Г. Воробьёва \\ Воронежский государственный университет
}

Поступила в редакцию 31 января 2019 г.

\begin{abstract}
Аннотация: в работе представлены результаты изучения влияния геологических работ на поверхностные воды и донные отложения Айхальского горнопромышленного комплекса (ГПК), как типового объекта геологоразведочной и горной деятельности зоны вечной мерзлоты. Выделены основные виды геологических работ, оказывающих негативное воздействие на изучаемые компоненты природной среды в уникальных природных условиях. Среди них: поисковые, разведочные, добычные и перерабатывающие работы. Определены основные загрязняющие элементы, к которым отнесены тяжёлье металлы ( $\mathrm{Zn}, \mathrm{Li}, \mathrm{Pb}, \mathrm{Cu}$, вымывваемые из пород отработки); источники воздействия, представленные элементами добывающей и перерабатывающей промылленности. В качестве природоохранных мероприятий с целью минимизации негативного воздействия на поверхностные воды и донные отложения предложено рациональное размещение водопропускных сооружений и устройств при строительстве дорог; проложение путей транспортировки буровых установок и их перемещение в период сохранения состояния сезонно-талого слоя; применение вертикальной планировки с ливневыми стоками и элементами активного дренирования надмёрзлотных стоков; создание искусственных техногенных геохимических барьеров карбонатного или карбонатно-глинистого типа; соотнесение проведения буровзрывных работ с метеоусловиями.

Ключевые слова: поверхностные воды и донные отложения; вечномёрзлые породы; воздействие геологоразведочной и горной деятельности; техногенез; геологические работы; комплекс природоохранных мероприятий для горнодобывающих предприятий криозоны.
\end{abstract}

\section{INFLUENCE OF GEOLOGICAL WORKS ON SURFACE WATER AND BOTTOM SEDIMENTS OF AYHALSKY MINING INDUSTRY (YAKUTIA)}

\begin{abstract}
: this work presents the results of studying the effect of geological work on surface water and bottom sediments of the Aikhal mining complex (GIC) as a typical object of geological exploration and mining activities in the permafrost zone. The main types of geological works that have a negative impact on the studied components of the environment in unique natural conditions are identified. Among them: prospecting, exploration, mining and processing work. The main polluting elements to which heavy metals ( $\mathrm{Zn}, \mathrm{Li}, \mathrm{Pb}, \mathrm{Cu}$, washed out from the mining rocks) are attributed; sources of exposure represented by elements of the mining and processing industries. As environmental measures to minimize the negative impact on surface water and sediment proposed rational placement of culverts and devices during the construction of roads; location of transportation routes for drilling rigs and their movement during the period of conservation of the seasonally thawed layer; use of vertical planning with storm drains and elements of active drainage of permafrost drains; creation of artificial man-made geochemical barriers of carbonate or carbonate-clay type; correlation of drilling and blasting operations with weather conditions.
\end{abstract}

Keywords: surface water and bottom sediments; permafrost; the impact of exploration and mining activities; technogenesis; geological work; set of environmental measures for cryozone mining enterprises.

Изучаемый район работ расположен в северовосточной части Средне-Сибирского плоскогорья в пределах территории Вилюйского траппового плато и принадлежит бассейнам рек Моркока и Алакит.
Рассматривая территорию Айхальского горнопромышленного комплекса (ГПК), можно сделать вывод, что она принадлежит к субарктическому климатическому поясу, который характеризуется продолжитель- 
ной (8 месяцев) холодной зимой, умеренно жарким летом и кратковременными переходными периодами.

Территория Айхальского ГПК относится к зоне распространения вечномерзлых пород и расположен на Вилюйском плато, в 500 км к северо-западу от г. Мирный.

Отрицательное воздействие вечной мерзлоты на поверхностные воды и донные отложения заключается в характерных ей различных криогенных процессах. К ним относятся мерзлотное пучение, формирование наледей, солифлюкция, замерзание подземных вод и т.д.

Долины водотоков на пересечении трапповых полей глубоковрезанные, каньонообразные, на участках развития осадочных толщ они значительно расширяются, а склоны долин становятся более пологими. Относительные превышения междуречий над тальвегами долин достигают 380-390 м. К днищам долин водотоков приурочены пойменные террасы, имеющие ширину от 150 до 300 м, а местами до 600 м.

Реки района мелководны, несудоходны, характеризуются непостоянным режимом и смешанным питанием, зимой почти полностью перемерзают. В период весеннего снеготаяния (конец мая - начало июня) на реках и ручьях уровень воды может повышаться на 1,5-2 м. На долю весеннего стока приходится в среднем 71,5\% годового. Меженный период начинается с конца июня - начала июля и прерывается периодическими паводками, вызванными атмосферными осадками.

Вода рек имеет незначительную минерализацию (до 0,5 г/л) и по составу относится к гидрокарбонатному типу.

В пределах траппового плато развиты термокарстовые озера изометричной или неправильноизометричной формы, площадью от 0,1 км $^{2}$ до 4,5 км² (оз. Ого-Кюель). Все озера мелководны, глубина их не превышает 1-2,5 м. Берега озер заболочены. Реки и озера района служат источниками пресной воды для технического и бытового водоснабжения.

В экономическом отношении район является одним из основных центров алмазодобывающей промышленности [1]. Основной населенный пункт - п. Айхал с населением около 17 тыс. человек. В поселке,

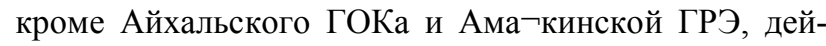
ствует еще ряд промышленных предприятий АК «АЛРОСА».

На всей территории района месторождения развиты многолетнемерзлые породы (ММП), входящие в криолитозону общей мощностью до 720 м.

Криолитозона характеризуется минимальными температурами на глубинах 100-140 м $\left(-3,4 \div-4,2^{\circ} \mathrm{C}\right)$, а нулевая изотерма проходит на глубине 630-720 м. Мощность многолетнемерзлых пород составляет 340 450 м (+110 $\div+180$ м абс). В соответствии с общепринятой классификацией в районе месторождения выделяются три типа подземных вод: надмерзлотные, межмерзлотные и подмерзлотные.

Надмерзлотные воды не оказывают практического влияния на обводненность месторождения и условия его отработки.

Межмерзлотные подземные воды представлены нижнеордовикским комплексом. С 1995 г. нижнеордовикский комплекс был вскрыт карьером тр. Айхал на отметках $+255 \div+250$ м абс. При вскрытии суммарный приток в карьер не превышал $15 \mathrm{~m}^{3} /$ сут, а при дальнейшей эксплуатации карьера наблюдалось лишь слабое высачивание подземных рассолов. Поступающий объем рассолов вывозился из карьера совместно с горной породой и не вызывал никаких осложнений при проведении добычных работ.

Подмерзлотные подземные воды представлены следующими водоносными комплексами:

- верхнекембрийским;

- среднекембрийским;

- нижнекембрийским;

- протерозойским.

Вышеперечисленные водоносные комплексы в районе месторождения Айхал вскрыты картировочными гидрогеологическими скважинами.

Поверхностные воды озер в районе имеют незначительное распространение. Большинство озер расположено на междуречьях и приурочено к обширным карстовым и термокарстовым понижениям. Наиболее крупное из них по площади - озеро Ого-Кюель $\left(4,5 \mathrm{\kappa m}^{2}\right)$ расположено на водоразделе р. Моркока и руч. Тегюрюк. Воды озер по своим физическим свойствам и химическому составу близки к водам рек и ручьев. Все озера района проточные.

Питание поверхностных вод происходит за счет атмосферных осадков и разгрузки надмерзлотных вод деятельного слоя.

Поверхностные воды на территории Айхальского ГПК образуют реки Моркока, Алакит, Марха, Тегерюк, руч. Сытыкан и Сохсоолох с их притоками и ряд озер. На ручье Сохсоолох в алмазоперерабатывающих целях создано одноименное водохранилище, которое расположено в пос. Айхал.

Следует отметить, что поверхностные воды озер, рек и ручьев являются единственным источником водоснабжения в пределах исследуемой площади.

Кроме природных уникальных условий вечной мерзлоты на компоненты природной среды влияют геологические работы, ведущиеся в данном районе с 90-х годов прошлого столетия. В представленной статье выделены основные виды работ, среди которых:

Поисковые работы представляют собой комплекс геологических работ, проводимых для выявления и оценки полезных ископаемых. Они включают геологическую и аэрогеологическую съёмки, обломочноречной, валунно-ледниковый, шлиховой, металлометрический, геохимический и геофизический методы поисков, создание редкой сети искусственных обнажений коренных пород путём расчисток их выходов, проходки канав, шурфов.

Разведочные работы - это комплекс работ, проводимых с целью промышленной оценки месторождения, то есть установления количества и качества по- 
лезного ископаемого, заключенного в месторождении, условий его залегания. Комплекс разведочных работ включает производство буровых, гидрогеологических и геофизических работ. В результате данных работ производятся неорганизованные выбросы в атмосферу пыли и газов; прокладка дорог; вырубка лесов; нарушение почвенного покрова.

В рамках разведочных работ проводятся также и взрывные работы, которые представляют собой совокупность производственных процессов по отделению от массива взрывом части горной породы с одновременным её раздроблением и перемещением. При их проведении последовательно осуществляется проходка зарядных полостей (шпуров, скважин, камер) для размещения зарядов взрывчатых веществ (BВ), заряжание ВВ, их забойка и возбуждение (инициирование) взрыва. На данном этапе происходят загрязнение (запыление и загазовывание) атмосферы; деформация земной поверхности; нарушение почвенного покрова; сокращение площадей продуктивных угодий различного назначения; ухудшение качества почв; ухудшение условий обитания растительности.

Добычные работы - комплекс процессов, необходимых для извлечения полезного ископаемого из недр на поверхность. В процессе добычных работ наблюдаются загрязнение атмосферы организованными выбросами; проведение горных выработок; извлечение полезных ископаемых, вмещающих и вскрышных пород; осушение месторождения; перенос поверхностных водоёмов и водотоков;

Перерабатывающие работы - совокупность производственных процессов по отделению вмещающих пород от полезного ископаемого. На данном этапе добывающих работ происходят сооружение отвалов, хвосто- и водохранилищ; сброс сточных вод; ухудшение качества вод в результате неблагоприятных изменений гидрохимических и биологических режимов поверхностных и подземных вод; эрозионные процессы; осаждение пыли и химических соединений вследствие выбросов в атмосферу от тягачей и тяжёлой техники; производственные и бытовые шумы; ухудшение качества почв; изменение облика территории; эрозионные процессы.

На территории Айхальского ГПК ведутся все перечисленные виды работ в пределах алмазодобывающих трубкок «Айхал», «Сытыкан» и «Юбилейная». Причём, каждый вид работ оказывает определённое негативное воздействие на поверхностные воды и донные отложения изучаемого района.

С 1955 г. в Айхальском районе ведётся алмазодобыча открытым карьерным способом на трёх месторождениях, среди которых трубки «Айхал», «Сытыкан» и «Юбилейная».

Месторождение «Айхал» было открыто 22 января 1960 г. Трубка «Айхал» расположена в северозападной Якутии, в 450 км севернее г. Мирный, в зоне многолетней мерзлоты. Месторождение приурочено к левому склону долины ручья Сохсоолох-Мархинский и представляет собой трубку взрыва, вытянутую в северо-восточном направлении [2].

В 1960-61 гг. трубка «Айхал» была разведана до глубины 400 м. В последние годы проведена доразведка месторождения до глубины 900 м. Айхальский карьер расположен на крутом левом склоне долины p. Сохсоолох и представляет собой типично нагорный карьер.

Специфика проведения перерабатывающих работ на территории Айхальского ГПК заключается в использовании специального раствора при технологии переработки породы для добычи алмазов. После проведения буровзрывных работ раздробленные кимберлиты транспортируются на перерабатывающую фабрику № 8. Выделение алмазов производится путем обработки породы карбонатным раствором. Высокощелочные сточные воды сбрасываются в Сохсоолохское водохранилище и имеют характерный голубой цвет (рис. 1).

Кимберлитовая трубка «Сытыканская» была открыта в августе 1955 г.; расположена в истоках ручья Сытыканский, в 27 км к северо-востоку от поселка Айхал.

Коренное месторождение алмазов трубки «Юбилейная» открыто в 1975 г., в 15 км к северо-западу от поселка Айхал. Промышленные руды представлены кимберлитами. Трубка также находится в зоне сплошного распространения многолетнемерзлых пород. В связи с наличием талых грунтов под озерами на карьере предусмотрены водоотливные установки.

\section{Методика исследований}

Оценка степени воздействия поисковых, разведочных, добычных и перерабатывающих работ проводилась:

- в зоне влияния добычных и перерабатывающих работ, которые ведутся на алмазных трубках Айхал, Юбилейная и Сытыкан;

- на геологоразведочном Алакит-Моркокинском объекте, который расположен в 40 км в юго-западном направлении от пос. Айхал и входит в пределы Айхальского ГПК;

- на территории проведения поисковых работ, расположенной южнее пос. Айхал (район рек Моркока, Делингде, Мас-Юрях, Тегюрюк и т.д.) (рис. 2).

Анализируя схему участков геологических работ в Айхальском ГПК (рис. 2), можно сделать вывод, что около $40 \%$ его территории занимают участки поисковых работ. В их состав входят аэросъемка, комплекс геолого-геофизических исследований, гравимагнитные, петрофизические, геохимические и шлиховые работы.

К юго-западу от поселка Айхал располагаются участки геологоразведочных работ, занимающие около $20 \%$ изучаемой территории. Данные участки относятся к геологоразведочному Алакит-Моркокинскому объекту, территория отнесена к перспективной на алмазоносность. Именно на указанном объекте велись буровые и взрывные работы с целью обнаружения коренных месторождений алмазов. 


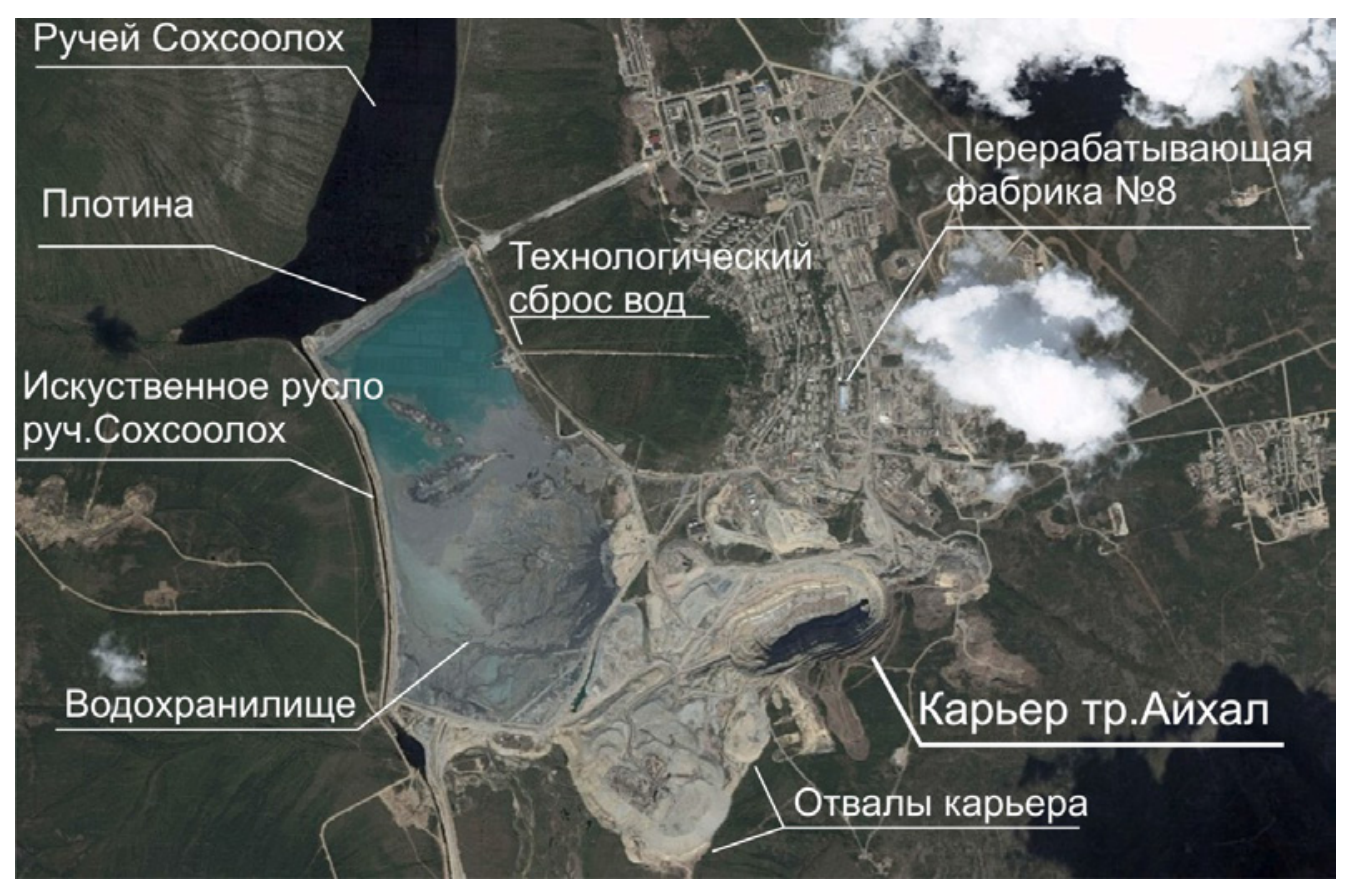

Puc. 1. Район добычных и перерабатывающих работ в Айхальском ГПК.

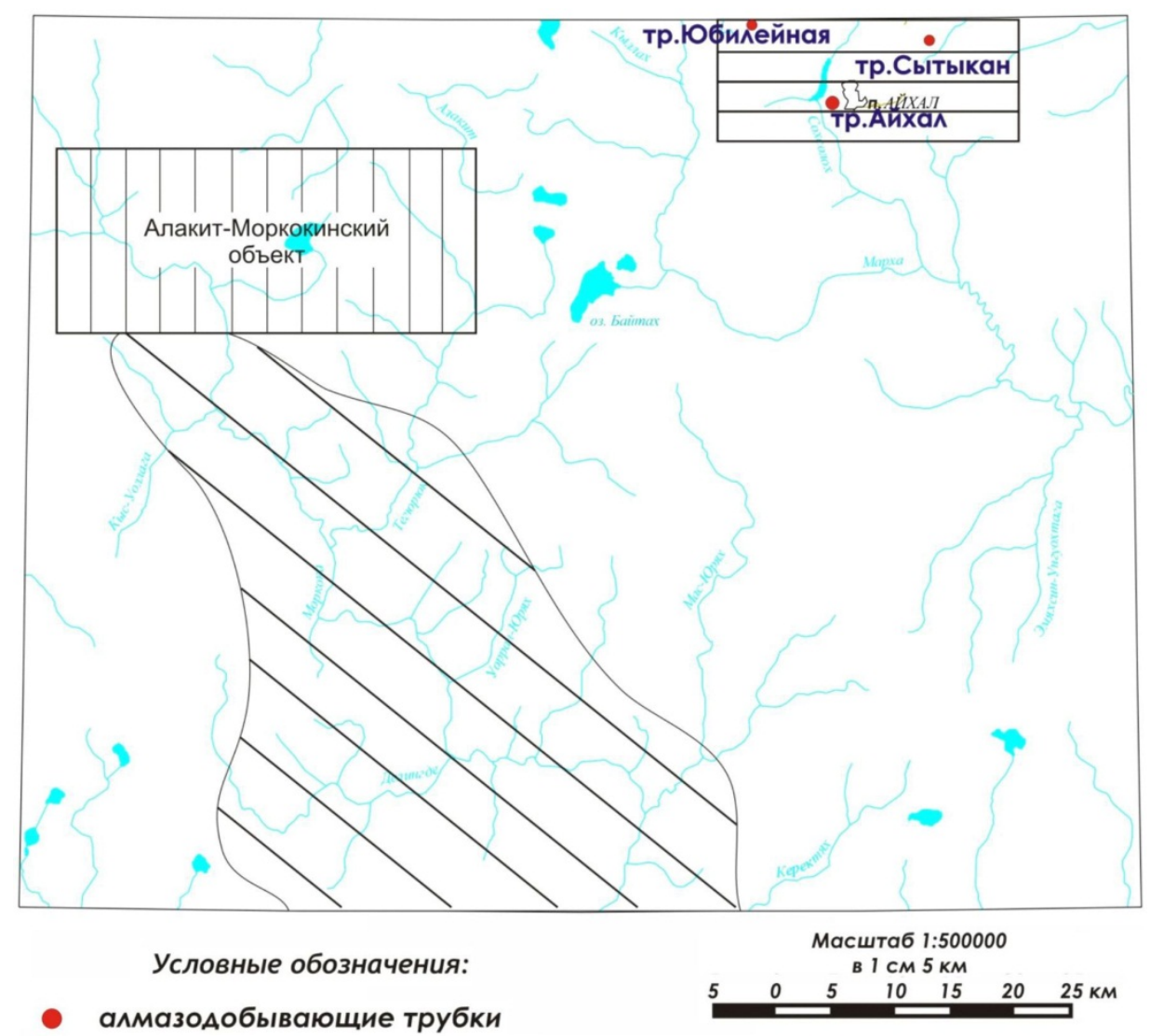

Участки:

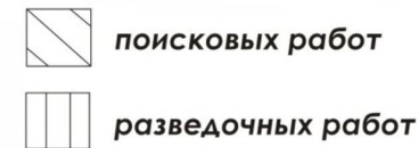

Аобычных и перерабатывающих работ

Puc. 2. Схема освоения территории Айхальского горнопромышленного комплекса. 
Около 5-7\% Айхальского ГПК занимают участки добычных и перерабатывающих работ. Они приурочены к алмазосодержащим трубкам Айхал, Сытыкан (Сытыканская) и Юбилейная и располагаются в северо-восточной части изучаемой территории.

Поверхностные водотоки опробовались с частотой, определяемой плотностью техногенной нагрузки. Пробы отбирались по основным водотокам Айхальского ГПК (р.Марха, р.Моркокка, р.Алакит, р.Сытыкан, р.Делингде, р.Тегюрюк, р.Кыллах, р.УэсяЮрягэ, руч. Сытакан и Сохсоолох) с шагом 1 км. Однако в пределах городских агломераций их плотность увеличивалась до 0,3 км. Особое внимание при пробоотборе обращалось на такие элементы техносферы, как ливневые и промышленные сбросы сточных вод, огородничество в поймах, расположение площадок выпаса скота, стоянок автотранспорта и т.д. При обнаружении подобных обстоятельств пробы воды отбирались выше и ниже объекта воздействия. Исследования проводились в меженный период, т.к. он является наиболее информативным относительно реально-

го состояния водного объекта. А максимальные уровни загрязнения фиксируются в паводковый период.

Схема опробования донных отложений привязана к схеме пробоотбора поверхностных вод. Пробы донных отложений набирались с глубины до 60 см. Всего было отобрано 354 пробы.

Эколого-гидрохимическая оценка состояния поверхностных вод проводилась путем нормирования истинных концентраций химических компонентов к ПДК по формуле 1:

$$
Z_{\phi_{i}}=\sum_{i=n}^{n} K_{\phi_{i}}-(n-1),
$$

где $K_{\phi_{i}}=C_{i} / C \phi_{i}-$ коэффициенты концентрации, нормированные на фоновые значения, $C_{i}$ - содержание химического элемента в пробе; $C \phi_{i}-$ фоновое содержание химического элемента, $n$ - число аномальных химических элементов, концентрации которых $\geq 1$.

Поверхностные воды изучались на содержание $\mathrm{Li}, \mathrm{Sr}, \mathrm{B}, \mathrm{Br}, \mathrm{Mn}, \mathrm{Cu}, \mathrm{Zn}$. В результате были выделены следующие зоны экологического состояния ГЭС [3] (табл. 1).

Таблица 1

Оиенка геоэкологического состояния поверхностных вод и донных отложений

\begin{tabular}{|c|c|c|c|}
\hline \multirow{2}{*}{ Оценка состояния ГЭС } & Донные отложения & \multicolumn{2}{|c|}{ Поверхностные воды } \\
\cline { 2 - 4 } & \multirow{2}{*}{ СП3 } & \multicolumn{2}{|c|}{ Загрязняющие элементы, ПДК } \\
\cline { 2 - 4 } & $<16$ & $1-2$ кл. оп-ти & $3-4$ кл. оп-ти \\
\hline Допустимое & $16-32$ & $1-2,5$ & $<1$ \\
\hline Умеренно опасное & $32-128$ & $2,5-5$ & $1-25$ \\
\hline Опасное & $>128$ & $5-10$ & $50-100$ \\
\hline Высоко опасное & \multirow{2}{*}{$>10$} & $>100$ \\
\hline Чрезвычайно опасное & \multirow{2}{*}{} & & \\
\hline
\end{tabular}

При оценке степени загрязнения донных отложений использовался суммарный показатель загрязнения, рассчитываемый по формуле 2 [4]:

$$
Z_{c_{i}}=\sum_{i=n}^{n} K_{k_{i}}-(n-1),
$$

где $K_{k_{i}}=C_{i} /$ ПДК $K_{i}-$ коэффициенты концентрации, нормированные на предельно допустимые концентрации, $C_{i}$ - содержание химического элемента в пробе; ПДК $\kappa_{i}$ предельно допустимая концентрация химического элемента; $n$ - число аномальных химических элементов, концентрации которых $\geq 1$.

Было изучено содержание таких химических элементов, как $\mathrm{Sc}, \mathrm{V}, \mathrm{Cr}, \mathrm{Co}, \mathrm{Cu}, \mathrm{Zn}, \mathrm{Sr}, \mathrm{Y}, \mathrm{Ba}, \mathrm{La}$ и $\mathrm{Pb}$. Степень загрязнения донных отложений определяется с помощью оценочной шкалы, приведенной в табл. 1.

\section{Результаты}

\section{A. Поверхностные воды}

Формирование химического состава поверхностных вод обусловлено влиянием природных и техногенных факторов. Среди природных важнейшими являются литологический состав подстилающих пород и геологические условия. К техногенным факторам относится алмазная промышленность. Рассматри- вая результаты проведенных исследований, можно сделать вывод, что большая часть рек района протекает по карбонатным отложениям и характеризуется допустимой оценкой экологического состояния. Среднее содержание химических элементов в водотоках, протекающих в естественных условиях (р. Делингде, р. Мас-Юрях, р. Тегюрюк и т.д.), незначительно отличается друг от друга и существенно различается по содержанию многих компонентов от рек, испытывающих техногенное воздействие (руч. Сохсолоох, р. Марха, руч. Сытыкан, р. Моркока) [5]. Подобными работами занимались такие авторы как Косинова И. И., Ильяш В. В., Ильяш Д. В., рассматривая территорию Воронежской антеклизы [12].

В местах проведения поисковых работ преобладают природные факторы формирования химического состава поверхностных вод. Максимальные концентрации цинка в водах р. Моркока отмечаются на участке реки, где она размывает породы кристаллического фундамента. Это приводит к формированию умеренно опасного экологического состояния ГЭС (рис. 3).

Негативное воздействие геологоразведочных работ, ведущихся на Алакит-Моркокинском объекте, подтверждается отклонением от природных концен- 
траций элементов-загрязнителей. Большая часть повышенных содержаний свинца территориально соответствует расположению участка, где бурение скважин производилось по наиболее густой сети. Так в районе о3. Ого-Кюэль фиксируется зона умеренно опасного экологического состояния поверхностных вод.

Влияние добычных и перерабатывающих работ на поверхностные воды выражается в повышенных содержания в них тяжелых металлов, источниками поступления которых являются отвалы алмазоносной отработки. При промывке данных отложений в поверхностные воды в растворимой форме поступают Zn, $\mathrm{Li}, \mathrm{Pb}, \mathrm{Cu}$, вымываемые из пород отработки.
Так ручей Сытыкан, в истоках которого ведется разработка алмазов одноименной трубки, характеризуется опасным экологическим состоянием. Воды ручья Сохсоолох в северной части изучаемой территории обладают опасным уровнем загрязнения. Влияние карьера трубки Айхал проявляется в повышенных содержаниях тяжелых металлов, в том числе лития. В техногенно образованном Сохсоолохском водохранилище, в котором ведется отстаивание горных пород, фиксируется высоко опасная оценка состояния поверхностных вод. Техногенное заражение ручья Сохсоолох фиксируется и в 8 км ниже трубки Айхал.

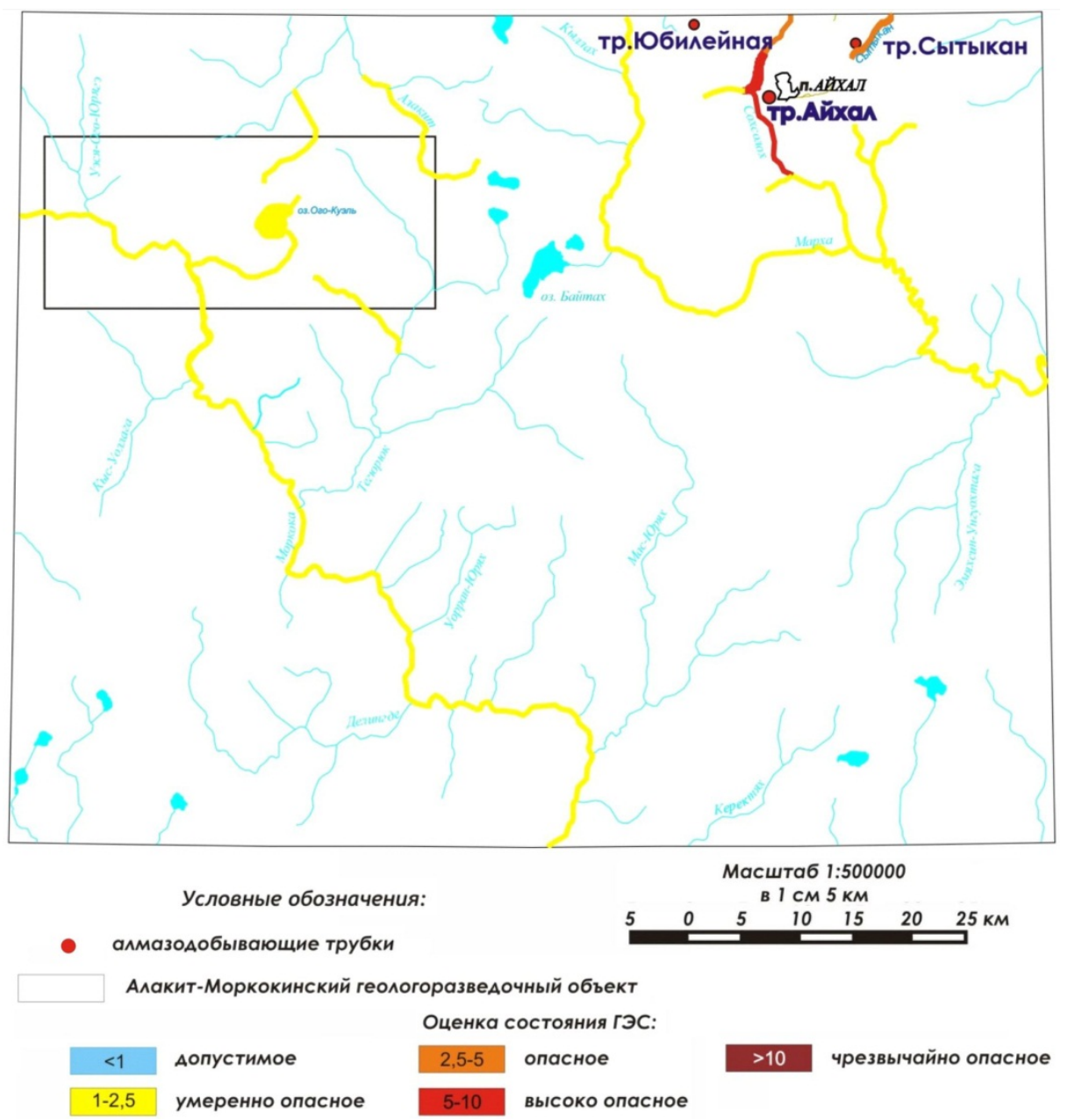

Puc. 3. Карта эколого-гидрохимической оценки поверхностных вод по содержанию цинка в Айхальском ГПК.

\section{Б. Донные отложения.}

Основные результаты, полученные при анализе степени загрязнения донных отложений на территории Айхальского ГПК по величине СПЗ, представлены в виде карты их экологического состояния (рис. 4).

Следует также отметить комплексное влияние на состав донных отложений природных и техногенных факторов. Так природные обусловлены наличием зон тектонических нарушений и проявлены в виде содержаний хрома, кобальта, иттрия, ниобия, скандия. Их аномальные концентрации приурочены к рекам, дре- нирующим породы кристаллического фундамента. Подобные природные аномалии фиксируются в долинах рек Моркока, Алакит.

Повышенное содержание свинца приурочено к местам проведения геологоразведочных работ на Алакит-Моркокинском объекте. Свинец имеет преимущественно техногенное происхождение, содержится в газовых выбросах двигателей внутреннего сгорания в виде тетраэтила свинца, а также относится к производству буровых работ на площади изучаемого объекта. Так донные отложения р. Уэся-Юрягэ, приустьевая 


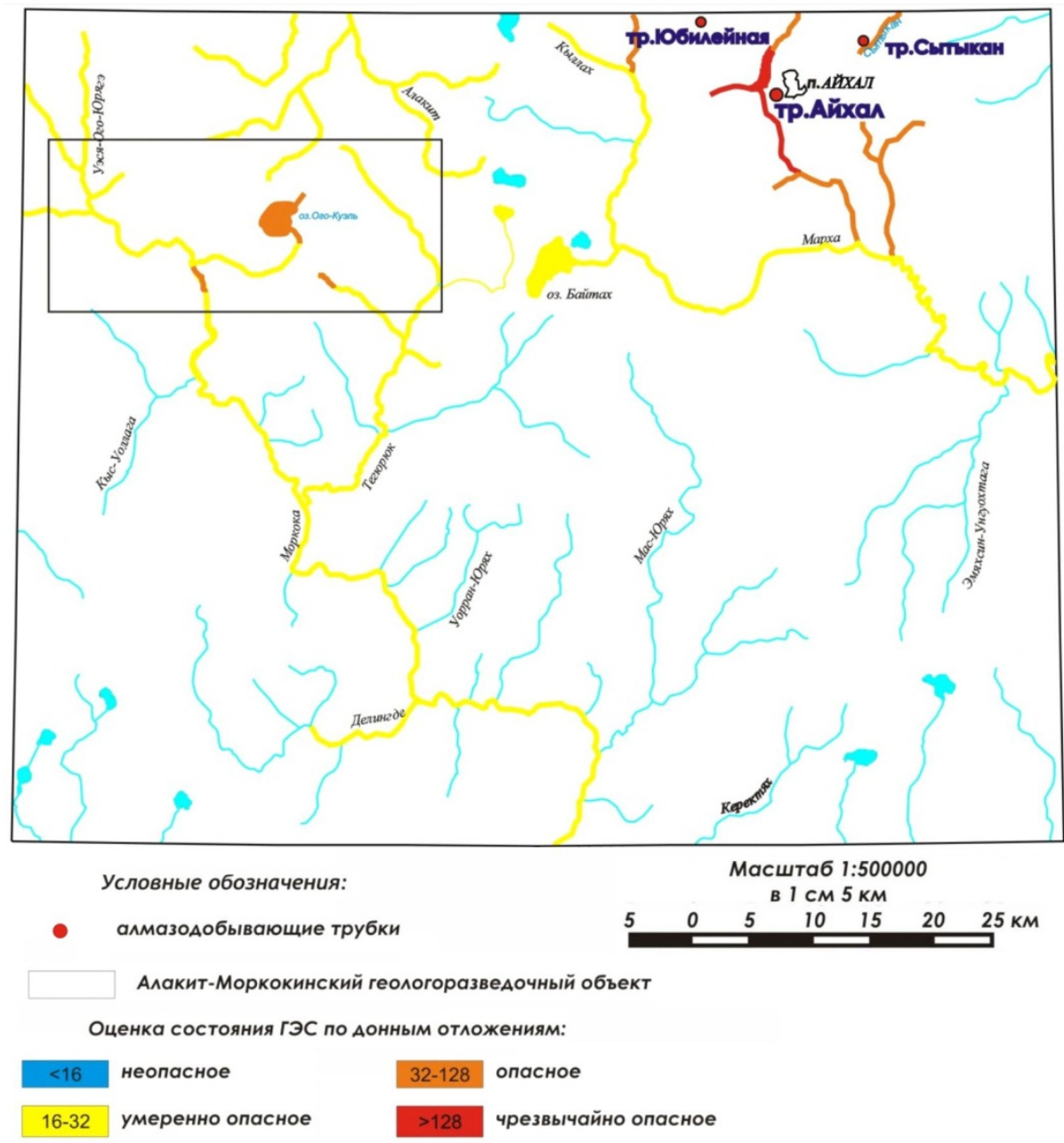

Puc. 4. Карта эколого-геохимической оценки донных отложений по величине СПЗ в Айхальском ГПК.

часть руч. Блудливый, оз. Ого-Кюэль и небольшой участок долины р. Моркока характеризуются опасным экологическим состоянием. Интенсивное проведение буровых работ с выемкой глубинных пород на поверхность также оказывают интенсивное воздействие на формирование химического состава поверхностных вод изучаемых водотоков.

В северо-восточной части изучаемой территории донные отложения характеризуются опасным и чрезвычайно опасным экологическим состоянием, что подтверждает интенсивное воздействие добычных и перерабатывающих работ. Пики загрязнения приурочены к местоположениям алмазодобывающих трубок Айхал, Сытыкан и Юбилейная. Основными загрязняющими элементами являются $\mathrm{Zn}, \mathrm{Pb}, \mathrm{Cu}, \mathrm{Ni}, \mathrm{Cr}, \mathrm{Co}$, которые поступают в донные осадки при буровзрывных работах.

К источникам воздействия перерабатывающих работ также относится Сохсоолохское водохранилище, где происходит отстаивание вмещающих горных пород, в состав которых входят свинец, цинк, медь, литий.

\section{Выводы}

Анализируя итоги проведенных работ, можно сделать вывод, что территории, характеризующиеся чрезвычайно опасным и высоко опасным состоянием компонентов природной среды, приурочены к местам проведения добычных и перерабатывающих работ. Загрязняющие элементы, поступающие в поверхностные воды при разработке и переработке алмазного вещества, переносятся на несколько десятков километров (до 40 км) и приводят к изменениям химического состава изучаемых компонентов природной среды, формируя опасные, высоко опасные и чрезвычайно опасные уровни загрязнения.

Негативное воздействие на поверхностные воды и донные отложения добычных работ выражено в виде:

- ветровой и водной транспортировки меди, никеля, свинца, цинка, лития на прилегающие к отвалам участки геоэкологической системы;

- нарушения водного режима при осушении месторождения и изменении поверхностных водотоков.

Переработка полезных ископаемых также формирует чрезвычайно опасное и опасное состояние поверхностных вод и донных отложений соответственно. Это проявлено в виде:

- нарушения гидрографической сети при создании водохранилищ и искусственных пойм;

- изменения положения и движения уровня подземных вод, что влияет на изменения условий водотоков; 
- загрязнения поверхностных и подземных вод сточными водами предприятия.

Разведочные и поисковые работы формируют состояния изучаемых компонентов ГЭС от опасного до умеренно опасного, что проявляется в виде:

- нарушения водного режима;

- загрязнение поверхностных вод и донных отложений.

В целом, воздействие геологических работ на поверхностные воды и донные отложения проявляются в виде различных видов изменений.

Гидрологические и гидрогеологические изменения обусловлены:

1. Дренажным воздействием подземных и открытых горных выработок.

2. Деформацией поверхности в результате ведения горных пород.

3. Смещением русел рек, строительством водоёмов, перепадов и других гидротехнических сооружений.

4. Загрязнением поверхностных вод.

5. Использованием поверхностных вод в целях хозпитьевого водоснабжения.

6. Перемещением глубинных мерзлотных вод высокой минерализации на поверхность вместе с вскрышными породами в отвалы, в результате чего формируются эколого-геохимические аномалии.

В результате этого воздействия происходит значительная трансформация гидросферы, которая проявляется в:

- изменении положения и движения уровня подземных вод и гидрографической сети;

- загрязнении вод неглубокозалегающих водоносных горизонтов, изменении водного режима почвенного слоя;

- уменьшении ресурсов подземных вод;

- развитии суффозии и механического уплотнения грунтов;

- изменении морфодинамического режима рек;

- создании искусственных пойм.

Химические изменения обусловлены:

1. Эмиссией газов и химически активной пыли.

2. Сбросом загрязненных вод.

3. Воздействием токсичных компонентов, содержащихся в породных отвалах и хвостохранилищах.

Загрязнение поверхностных вод и донных отложений приводит к негативным последствиям, отражающимся на всех компонентах природной среды, в том числе и растительность [11].

На основании проведенной работы предложен ряд природоохранных мероприятий для горнодобывающих предприятий, расположенных в зоне распространения вечномерзлых пород. С целью минимизации негативного воздействия на поверхностные воды и донные отложения следует отметить ряд направлений, по которым необходимо внедрение организационных, инженерных и защитных мероприятий.

Функционирование комплекса горноперерабатывающего предприятия должно учитывать следующее:

1. Соблюдение жестких правил размещения обога- тительных фабрик с учетом метеорологической ситуации. Важно исключить размещение жилья и обеспечивающих комфортность проживания объектов в зоне максимального воздействия ГОКа. Данное требование объясняется использованием вод ручья Сохсоолох в питьевых целях населением пос.Айхал.

2. Рациональное размещение водопропускных сооружений и устройств при строительстве дорог, которые обеспечат минимальное нарушение естественного режима поверхностной и грунтовой воды, а также снизят риск таяния вечномерзлых пород. Применение вертикальной планировки с ливневыми стоками и элементами активного дренирования надмёрзлотных стоков.

3. Снижение интенсивности нарушения криозоны и миграции загрязняющих компонентов из водохранилища в поверхностные воды рекомендуется путем создания барьера карбонатно-глинистого состава, отделяющей чашу водохранилища от поверхностных вод. Применение данного метода обусловлено недостаточным уровнем препятствия фильтрации растворенных солей, создаваемым дамбами.

4. Создание системы очистных сооружений, характеризующихся механическим, физико-химическим и биологическим средствами очистки стоков. Рекомендация применения данного метода обосновывается наличием вечномерзлых пород, расположенных в 2030 см от земной поверхности. Они препятствуют проникновению загрязняющих веществ в глубинные горизонты, тем самым способствуют концентрирование загрязняющих веществ в поверхностных водотоках.

5. Применение в качестве транспортных путей замерзших речных долин. Это обосновывается сезонным мёрзлым состоянием водных объектов, являющихся более защищёнными от внешнего воздействия в зимнее время.

6. Соотнесение проведения буровзрывных работ с метеоусловиями, что позволит снизить радиус их воздействия. К таковым относятся: наличие атмосферных осадков, направление, а также скорость ветра, низкая температура воздушных масс. Использование местных признаков погоды позволяет осуществить корректуру внешней гидрометеорологической информации и составить краткосрочный прогноз на ближайшие 6-12 часов. В частности при прогнозе чрезвычайных погодных ситуаций (большими скоростями ветра) необходимо корректировать график проведения буровзрывных работ.

\section{ЛИТЕРАТУРА}

1. Глушкова, В. Г. Эколого-экономические проблемы России и ее регионов: Учебное пособие для студентов экономических вузов. - 2-е изд., испр. и доп. / Под общ.ред. В. Г. Глушковой. - М.,: Московский Лицей, 2003. - 304 с.

2. Алмазные месторождения Якутии. ГОНТИ / А. П. Бобриевич [и др.]. - М., 1959. - 528 с.

3. Косинова, И. И. Методы эколого-геохимических, эколого-геофизических исследований и рациональное недропользование / И. И. Косинова, В. А. Богословский, В. А. Бударина. - Воронеж 2004. - 281 c. 
4. МУ 2_1_7_730-99 - Гигиеническая оценка качества почвы населенных мест (ПДК).

5. Иванов, В. В. Отчет о результатах поисков коренных месторождений алмазов на Алакит-Моркокинском междуречье. / В. В. Иванов, Е. Н. Иванюшина. - Айхал, 2005. - 268 с.

6. Косинова, И. И. Методы эколого-геохимических, эколого-геофизических исследований и рациональное недропользование. / И. И. Косинова, В. А. Богословский, В. А. Бударина. - Воронеж, 2004. - 281 с.

7. Трансформация экологических функций литосферы в эпоху техногенеза: Уч. пособие / В. Т. Трофимов [и др.]. М.: Изд-во «Ноосфера», 2006. - 720 с.

8. Мильков, Ф. Н. Физико-географическое и экологогеографическое районирование. Их соотношение / Ф. Н. Мильков // Эколого-географические районы Воронежской области. - Воронеж, 1996. - С. 47-48.

9. Хованская, М. А. Эколого-геохимическая оценка территории поисковых и геологоразведочных работ на Алакит-
Моркокинском объекте (Саха-Якутия). / М. А. Хованская, И. И. Косинова // Вестн. Воронеж. гос. ун-та. Сер.: Геология. -2011 . - № 1. - С. 275-280 .

10. Хованская, М. А. Методика оценки комфортности жизнедеятельности в горнодобывающих районах. / М. А. Хованская, И. И. Косинова // Известия высших учебных заведений. Геология и разведка. Издательство: Российский государственный геологоразведочный университет им. С. Орджоникидзе (Москва). - 2014 - № 6 - 54-58.

11. Косинова. И. И. Методика геоэкологической биоиндикации георисков техногенно-трансформированных территорий / И. И. Косинова, О. В. Базарский, С. Н. Козинцев // Геориск. - 2012. - № 3. - С. 22-25.

12. Косинова, И. И. Литологический фактор как одна из причин неравномерности развития циркументов на территории Воронежской антеклизы. / И. И. Косинова, В. В. Ильяш, Д. В. Ильяш // Вестн. Воронеж. гос. ун-та. Сер.: Геология. - 2013. - № 1. - С. 214-218.

\section{Voronezh State University}

Khovanskaia M. A., lecturer, PhD in Geography

E-mail: mashunia86@yandex.ru

Tel.: +7 (473) 2208289

E-mail: mashunia86@yandex.ru; Tел.: +7 (473) 2208289

Мария Геннадьевна Воробьёва, доцент, кандидат геологоминералогических наук

E-mail:mzaridze@mail.ru

Тел.: +7 (473) 2208289
Vorobieva M. G., lecturer, PhD in Geological and Mineralogical Sciences

E-mail:mzaridze@mail.ru

Tel.: +7 (473) 2208289 